\title{
Possible Role of Cytosolic Free Calcium Concentrations in Mediating Insulin Resistance of Obesity and Hyperinsulinemia
}

\author{
B. Draznin, K. E. Sussman, R. H. Eckel, M. Kao, T. Yost, and N. A. Sherman \\ The Research Service and Department of Medicine, Veterans Administration Medical Center; \\ and The University of Colorado Health Sciences Center, Denver, Colorado 80220
}

\begin{abstract}
Insulin- and glyburide-stimulated changes in cytosolic free calcium concentrations $\left(\left[\mathrm{Ca}^{2+}\right] \mathrm{i}\right)$ were studied in gluteal adipocytes obtained from six obese women (139 $\pm 3 \%$ ideal body wt) and six healthy, normal weight age- and sex-matched controls. Biopsies were performed after an overnight fast and twice (at 3 and $6 \mathrm{~h}$ ) during an insulin infusion $\left(40 \mathrm{mU} / \mathrm{m}^{2}\right.$ per $\mathrm{min}$ ) (euglycemic clamp). In adipocytes obtained from normal subjects before insulin infusion, insulin $(10 \mathrm{ng} / \mathrm{ml})$ increased $\left[\mathrm{Ca}^{2+}\right] \mathrm{i}$ from $146 \pm 26 \mathrm{nM}$ to $391 \pm 66 \mathrm{nM}$. Similar increases were evoked by $2 \mu \mathrm{M}$ glyburide (329 $\pm 41 \mathrm{nM})$. After $3 \mathrm{~h}$ of insulin infusion, basal $\left[\mathrm{Ca}^{2+}\right] \mathrm{i}$ rose to $234 \pm 21 \mathrm{nM}$, but the responses to insulin and glyburide were completely abolished. In vitro insulin-stimulated 2-deoxyglucose uptake was reduced by insulin and glucose infusion (25\% stimulation before infusion, $5.4 \%$ at $3 \mathrm{~h}$, and $0.85 \%$ at $6 \mathrm{~h}$ of infusion).

In obese patients, basal adipocyte $\left[\mathrm{Ca}^{2+}\right] \mathrm{i}$ was increased (203 $\pm 14 \mathrm{nM}, P<0.05$ vs. normals). The $\left[\mathrm{Ca}^{2+}\right]$ response demonstrated resistance to insulin $(230 \pm 23 \mathrm{nM})$ and glyburide $(249 \pm 19 \mathrm{nM})$ stimulation. Continuous insulin infusion increased basal $\left[\mathrm{Ca}^{2+}\right] \mathrm{i}(244 \pm 24 \mathrm{nM})$ and there was no response to either insulin or glyburide at 3 and $6 \mathrm{~h}$ of study.

Rat adipocytes were preincubated with 1-10 $\mathrm{mM}$ glucose and $10 \mathrm{ng} / \mathrm{ml}$ insulin for $24 \mathrm{~h}$. Measurements of 2-deoxyglucose uptake demonstrated insulin resistance in these cells. Under these experimental conditions, increased levels of $\left[\mathrm{Ca}^{2+}\right]$ that were no longer responsive to insulin were demonstrated. Verapamil in the preincubation medium prevented the development of insulin resistance.
\end{abstract}

\section{Introduction}

The role of intracellular calcium as a mediator of insulin action was originally proposed by Clausen et al. in 1974 (1) and by Kissebah et al. in 1975 (2). Since then, considerable evidence favoring this hypothesis has been accumulated (3-5). Although some investigators failed to observe a relationship between calcium and insulin action $(6,7)$, diverse aspects of insulin action have been demonstrated to be dependent upon extracellular and cytoplasmic $\mathrm{Ca}^{2+}(8-14)$.

\footnotetext{
Address reprint requests to Dr. Boris Draznin, Veterans Administration Medical Center, Box 111-H, 1055 Clermont Street, Denver, CO 80220.

Received for publication 12 April 1988 and in revised form $1 \mathrm{July}$ 1988.
}

The Journal of Clinical Investigation, Inc.

Volume 82, December 1988, 1848-1852
Using a new calcium indicator (fura-2), we recently demonstrated that insulin and glyburide are capable of increasing cytosolic free calcium concentrations $\left(\left[\mathrm{Ca}^{2+}\right] \mathrm{i}\right)^{1}$ in isolated rat adipocytes, primarily by enhancing $\mathrm{Ca}^{2+}$ transport across plasma membranes (15).

In the present study we have attempted to answer three questions: $(a)$ do insulin and glyburide increase $\left[\mathrm{Ca}^{2+}\right] \mathrm{i}$ in adipocytes obtained from normal subjects; $(b)$ are similar effects of insulin and glyburide observed in adipocytes isolated from patients with moderate obesity; and $(c)$ does in vivo hyperinsulinemia alter the cellular response to insulin and glyburide stimulation. In particular, we focused on the role of $\left[\mathrm{Ca}^{2+}\right] \mathrm{i}$ in modulating cellular sensitivity. The latter studies were performed during a 6-h insulin infusion (euglycemic clamp).

\section{Methods}

Materials. Porcine insulin was a gift from Eli Lilly Co. (Indianapolis, IN) and glyburide was generously supplied by Upjohn Co. (Kalamazoo, MI). Fura-2 and fura-2AM were purchased from Behring Diagnostics (San Diego, CA) and collagenase was obtained from Worthington Biochemical Corp. (Freehold, NJ).

Experimental design. Gluteal adipose tissue was obtained by needle biopsy in six obese women ( $139 \pm 3 \%$ ideal body wt) and six healthy, normal weight age- and sex-matched controls. The biopsies were performed after an overnight fast and twice (at 3 and $6 \mathrm{~h}$ ) during insulin infusion $\left(40 \mathrm{mU} / \mathrm{m}^{2}\right.$ per min) (euglycemic clamp) as previously described (16). Blood glucose levels in all patients and control subjects were maintained in the range of $85-95 \mathrm{mg} / \mathrm{dl}$. Adipocytes were isolated by the method of Rodbell (17). Obese subjects were studied before and 3 mo after moderate weight loss (down to $127 \pm 4 \%$ ideal body wt). During these 3 mo they were maintained on an isocaloric weight maintenance diet. Because weight reduction did not alter basal or insulinand glyburide-stimulated $\left[\mathrm{Ca}^{2+}\right] \mathrm{i}$, the results were combined for the sake of clarity.

Measurements of $\left[\mathrm{Ca}^{2+}\right] \mathrm{i}$. These measurements were performed as previously described $(15,18)$ using a spectrofluorometer (model 340; Turner Designs, Mountain View, CA). During fura-2 loading (45 min at $37^{\circ} \mathrm{C}$ ) and $\mathrm{Ca}^{2+}$ measurements the cells were incubated in $2.4 \mathrm{ml}$ of Krebs-Hepes buffer containing $1 \mathrm{mM} \mathrm{CaCl}, 118.4 \mathrm{mM} \mathrm{NaCl}, 4.69$ $\mathrm{mM} \mathrm{KCl}, 1.2 \mathrm{mM} \mathrm{MgCl}_{2}, 1.18 \mathrm{mM} \mathrm{KH}_{2} \mathrm{PO}_{4}, 1.25 \mathrm{mM} \mathrm{NaHCO}_{3}, 20$ $\mathrm{mM}$ Hepes, $5 \mathrm{mg} / \mathrm{ml} \mathrm{BSA}$, and $30 \mathrm{mg} / \mathrm{dl}$ glucose at $\mathrm{pH}$ 7.4. The final cell concentration was $\sim 2 \times 10^{5}$ cells $/$ cuvette (or $8 \times 10^{4}$ cells $/ \mathrm{ml}$ ) and the measurements were obtained before and $10 \mathrm{~min}$ after additions of either insulin $(10 \mathrm{ng} / \mathrm{ml})$ or glyburide $(2 \mu \mathrm{M})$. The fluorescence of the extracellular fura-2 was estimated by adding $\mathrm{MnCl}_{2}(50 \mu \mathrm{M})$, which quenches extracellular fura-2. $\mathrm{MnCl}_{2}$ was then chelated by the addition of $100 \mu \mathrm{M}$ pentetic acid. The estimate of extracellular fura- 2 was made before stimulation of the cells with insulin, glucose, or glyburide. The fluorescence of either the buffers used in these studies or of tissues (without fura-2) was $10-13 \%$ of that observed with the cells loaded

1. Abbreviations used in this paper: $\left[\mathrm{Ca}^{2+}\right] \mathrm{i}$, cytosolic free calcium concentrations. 

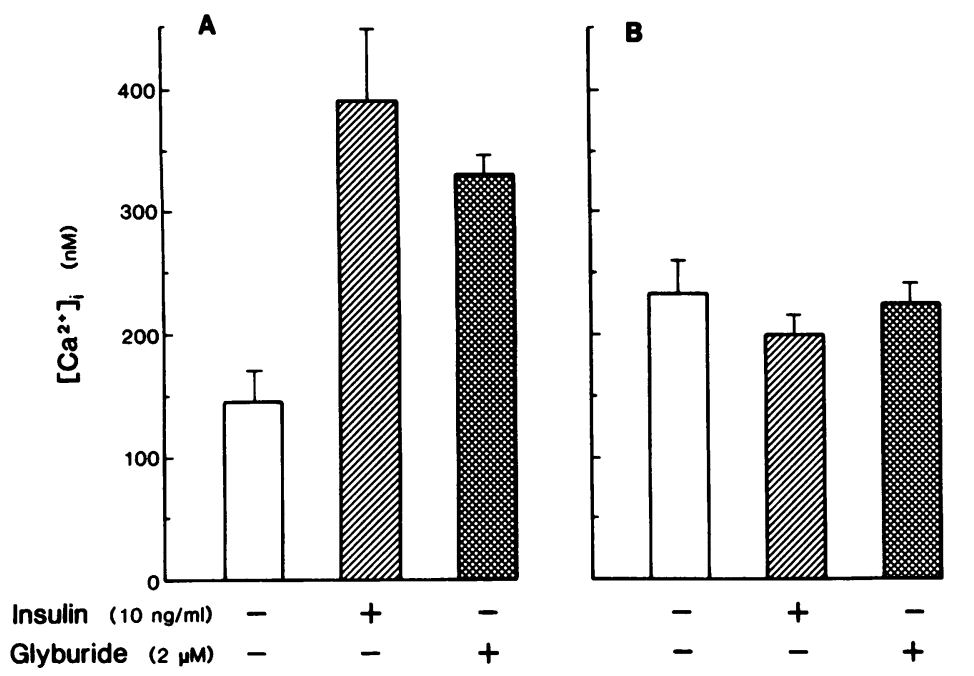

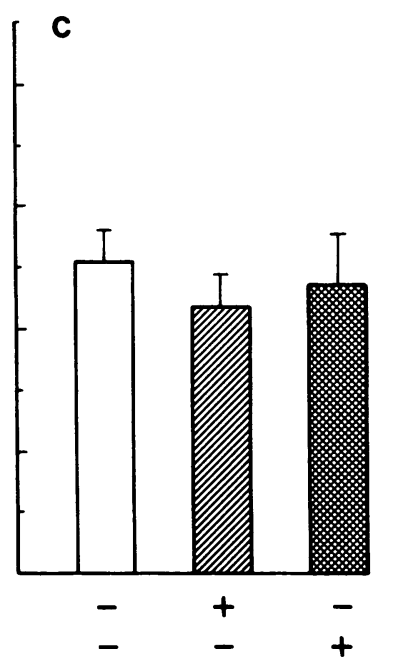

Figure 1. Effect of insulin and glyburide on $\left[\mathrm{Ca}^{2+}\right] \mathrm{i}$ in adipocytes obtained from six normal women after overnight fast $(A)$, at the 3rd $(B)$ and 6th $(C) \mathrm{h}$ of euglycemic clamp. Results represent mean \pm SEM. Control values for $\left[\mathrm{Ca}^{2+}\right] \mathrm{i}$ represent time controls; that is, the levels of $\left[\mathrm{Ca}^{2+}\right] \mathrm{i}$ at 0 , 3 , and $6 \mathrm{~h}$ of clamp but before in vitro additions of either insulin or glyburide. with the probe. Cellular and buffer fluorescence did not change in response to either glucose, insulin, or glyburide. Results are presented as mean \pm SEM and compared using paired or unpaired $t$ tests.

2-Deoxyglucose uptake. Adipocytes $\left(2 \times 10^{5}\right.$ cells) were incubated in the absence and in the presence of insulin $(25 \mathrm{ng} / \mathrm{ml})$ for $30 \mathrm{~min}$ at $37^{\circ} \mathrm{C}$. Glucose uptake was initiated by the addition of $\left[{ }^{3} \mathrm{H}\right] 2$-deoxyglucose $(0.2 \mu \mathrm{Ci})$. After $3 \mathrm{~min}$ of incubation the reaction was terminated by transferring $200-\mu \mathrm{l}$ aliquots of incubation mixture to the microfuge tubes containing $100 \mu \mathrm{l}$ silicone oil and centrifuging the tubes in a microfuge (Beckman Instruments, Inc., Palo Alto, CA). The cell pellets were counted for radioactivity present in a liquid scintillation counter (Beckman Instruments, Inc.).

In vitro studies with rat adipocytes. Adipocytes isolated by the method of Rodbell (17) were preincubated for $24 \mathrm{~h}$ as previously described by Marshall et al. (19) and Garvey et al. (20). The incubation media contained either 1 or $10 \mathrm{mM}$ glucose with or without $10 \mathrm{ng} / \mathrm{ml}$ insulin. After preincubation, the cells were washed three times and incubated for $\mathbf{4 0} \mathrm{min}$ in glucose- and insulin-free medium to eliminate any possible influence of high glucose or insulin present during the 24-h preincubation. The cells were resuspended in KRB and divided into two groups for 2-deoxyglucose uptake and $\left[\mathrm{Ca}^{2+}\right]$ i determinations as described above.

\section{Results}

The basal, nonstimulated level of $\left[\mathrm{Ca}^{2+}\right] \mathrm{i}$ in adipocytes obtained from the control subjects before insulin infusion was $146 \pm 26 \mathrm{nM}$. Incubation of these adipocytes with insulin (10 $\mathrm{ng} / \mathrm{ml}$ ) for $10 \mathrm{~min}$ at $37^{\circ} \mathrm{C}$ resulted in an increase in $\left[\mathrm{Ca}^{2+}\right]$ i to $391 \pm 66 \mathrm{nM}$ (Fig. 1 A). A similar increase was evoked by $2 \mu \mathrm{M}$ glyburide $(329 \pm 41 \mathrm{nM})$. In adipocytes obtained after $3 \mathrm{~h}$ of insulin infusion $\left(40 \mathrm{mU} / \mathrm{m}^{2}\right.$ per $\left.\mathrm{min}\right)$, basal $\left[\mathrm{Ca}^{2+}\right] \mathrm{i}$ rose to $234 \pm 21 \mathrm{nM}$ (Fig. $1 \mathrm{~B}$ ), but responses of these adipocytes to both insulin and glyburide were completely abolished $(197 \pm 13$ $\mathrm{nM}$ and $224 \pm 5 \mathrm{nM}$, respectively). [ $\left.\mathrm{Ca}^{2+}\right] \mathrm{i}$ continued to increase during insulin infusion, reaching $255 \pm 24 \mathrm{nM}$ at the 6 th $\mathrm{h}$ of the infusion (Fig. $1 C$ ). There was no further stimulation by either insulin or glyburide $(214 \pm 22 \mathrm{nM}$ and $235 \pm 40 \mathrm{nM}$, respectively).

To examine how this acquired inability of insulin to increase $\left[\mathrm{Ca}^{2+}\right] \mathrm{i}$ related to insulin action on glucose uptake, we studied basal and insulin-stimulated 2-deoxyglucose uptake in the fat cells obtained from three normal individuals at 0,3 , and $6 \mathrm{~h}$ of euglycemic clamp. The gluteal biopsies were obtained in the manner identical to those used to study $\left[\mathrm{Ca}^{2+}\right]$ i.
Before insulin and glucose infusion, insulin increased in vitro 2-deoxyglucose uptake by $24 \%$ (Fig. 2). At the 3rd and 6th h of euglycemic glucose clamp, the unstimulated (basal) levels of 2-deoxyglucose uptake were unchanged, but insulin-stimulated values were significantly reduced when compared with preclamp studies (Fig. 2).

In obese patients before insulin infusion, basal adipocyte $\left[\mathrm{Ca}^{2+}\right] \mathrm{i}$ increased compared with normal subjects $(203 \pm 14$ $\mathrm{nM}, P<0.05)$. The $\left[\mathrm{Ca}^{2+}\right] \mathrm{i}$ response of these adipocytes demonstrated resistance to both insulin $(230 \pm 23 \mathrm{nM}, 12 \%$ increase) and glyburide ( $249 \pm 19 \mathrm{nM}, 16 \%$ increase) (Fig. 3$)$. The comparison of these results with those obtained in normal individuals is shown in Fig. 4. Continuous infusion of insulin in obese patients further increased basal $\left[\mathrm{Ca}^{2+}\right] \mathrm{i}(244 \pm 24 \mathrm{nM}$ at $3 \mathrm{~h}$ and $252 \pm 32 \mathrm{nM}$ at $6 \mathrm{~h}$ ) and, similar to the controls, there was no response of the isolated adipocytes to either insulin or glyburide at 3 and $6 \mathrm{~h}$ of study.

If glucose and/or insulin infusion induce insulin resistance in adipocytes within $3 \mathrm{~h}$, this phenomenon should be reproducible in vitro. To examine this possibility, we incubated freshly isolated rat adipocytes for $24 \mathrm{~h}$ in the presence of either 1 or $10 \mathrm{mM}$ glucose with or without $10 \mathrm{ng} / \mathrm{ml}$ insulin. A similar experimental approach was previously used by Garvey et al. (20), who studied rat adipocytes, and by Sinha et al. (21), who studied human adipocytes. After a 24-h preincubation period, the adipocytes were washed with insulin- and glucosefree medium to deactivate the glucose transport system. These cells were then used to determine 2-deoxyglucose uptake and

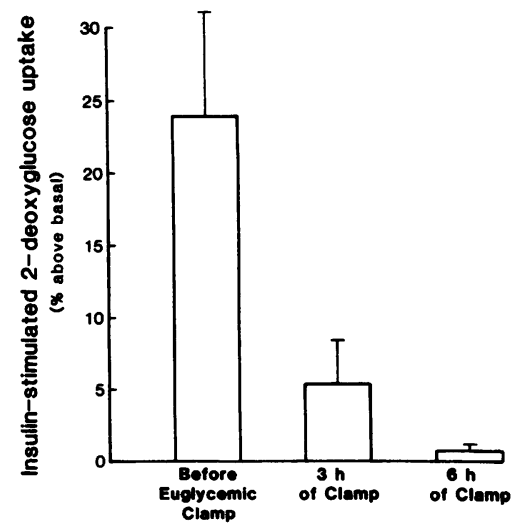

Figure 2. Insulin-stimulated 2-deoxyglucose uptake in adipocytes obtained by gluteal biopsy from three normal individuals before and during euglycemic clamp. Results represent mean \pm SEM of three determinations. 


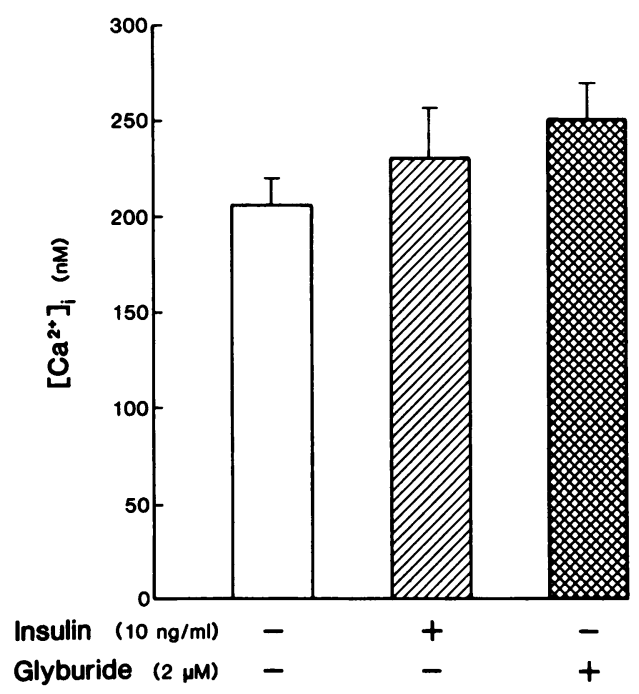

Figure 3. Effect of insulin and glyburide on $\left[\mathrm{Ca}^{2+}\right] \mathrm{i}$ in adipocytes obtained from six obese women after overnight fast. Results represent mean \pm SEM.

$\left[\mathrm{Ca}^{2+}\right]$ i. In adipocytes preincubated with $1 \mathrm{mM}$ glucose, both in the presence and in the absence of insulin, subsequent addition of insulin stimulated 2-deoxyglucose uptake by $\sim 100-115 \%$ (Fig. 5). The presence of insulin $(10 \mathrm{ng} / \mathrm{ml})$ in the 24-h preincubation media did not alter either basal or insulin-stimulated 2-deoxyglucose uptake.

In contrast to preincubations with $1 \mathrm{mM}$ glucose, the presence of $10 \mathrm{mM}$ glucose for $24 \mathrm{~h}$ significantly reduced insulinstimulated 2-deoxyglucose uptake $(P<0.01)$. Insulin in the preincubation media reduced both basal and insulin-stimulated glucose uptake (Fig. 5).

To examine whether this glucose- and insulin-induced insulin resistance was related to the levels of $\left[\mathrm{Ca}^{2+}\right] \mathrm{i}$, we measured $\left[\mathrm{Ca}^{2+}\right] \mathrm{i}$ in adipocytes preincubated under the same conditions used in the experiments with glucose uptake described above (Fig. 5). Insulin increased $\left[\mathrm{Ca}^{2+}\right] \mathrm{i}$ in adipocytes preincubated with low glucose $(1 \mathrm{mM})$ in the presence or in the absence of insulin. Basal $\left[\mathrm{Ca}^{2+}\right] \mathrm{i}$ was not increased by the 24-h preincubation with $10 \mathrm{mM}$ glucose, but in these adipocytes acute addition of insulin failed to stimulate $\left[\mathrm{Ca}^{2+}\right]$ i. Preincubation of adipocytes with both $10 \mathrm{mM}$ glucose and $10 \mathrm{ng} / \mathrm{ml}$

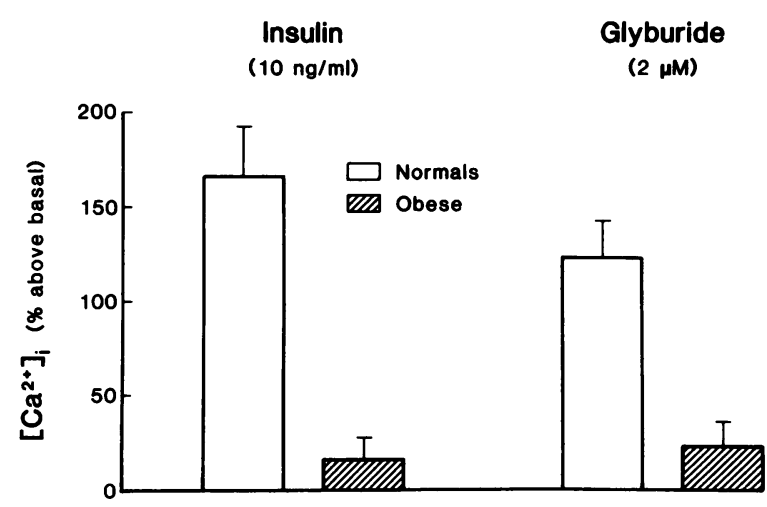

Figure 4. Effect of insulin and glyburide upon $\left[\mathrm{Ca}^{2+}\right] \mathrm{i}$ in adipocytes obtained from six normal weight controls and six obese women after overnight fast. Results represent mean \pm SEM; $P<0.01$ (obese vs. normals).

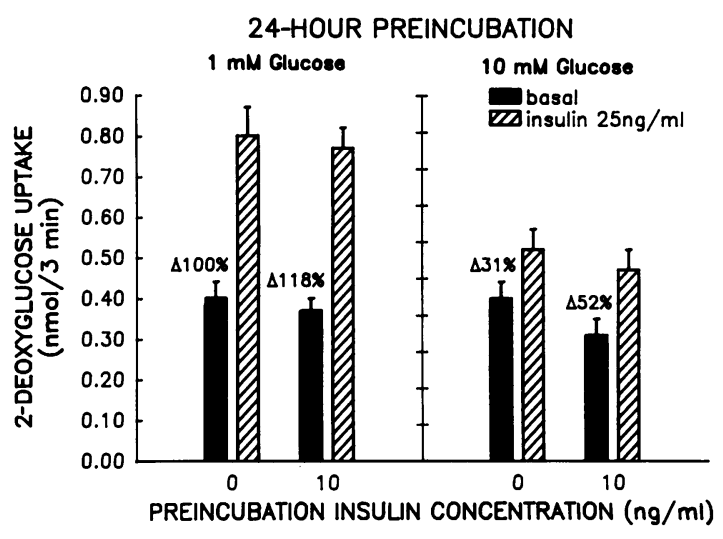

Figure 5. Effect of 24-h preincubation with 1 and $10 \mathrm{mM}$ glucose (with or without $10 \mathrm{ng} / \mathrm{ml}$ insulin) on basal and insulin-stimulated 2deoxyglucose uptake in rat adipocytes. Results represent the mean \pm SEM of five to eight experiments. $\Delta \%, \%$ stimulation by insulin.

insulin raised basal $\left[\mathrm{Ca}^{2+}\right] \mathrm{i}$ and eliminated the effect of insulin in increasing $\left[\mathrm{Ca}^{2+}\right] \mathrm{i}$ (Fig. 6), inducing a picture similar to that observed in adipocytes obtained during euglycemic clamp.

If changes in $\left[\mathrm{Ca}^{2+}\right] \mathrm{i}$ are related to the glucose- and insulin-induced insulin resistance, then inhibiting an increase in $\left[\mathrm{Ca}^{2+}\right] \mathrm{i}$ may prevent insulin resistance. Since insulin increases $\left[\mathrm{Ca}^{2+}\right] \mathrm{i}$ by enhancing $\mathrm{Ca}^{2+}$ influx via voltage-dependent $\mathrm{Ca}^{2+}$ channels (15), we incubated adipocytes as described above in the presence of $30 \mu \mathrm{M}$ verapamil. This $\mathrm{Ca}^{2+}$ channel blocker reduced the levels of $\left[\mathrm{Ca}^{2+}\right]$ i from $162 \pm 15 \mathrm{nM}$ to $99 \pm 13 \mathrm{nM}$ with $10 \mathrm{mM}$ glucose alone and from $239 \pm 31$ to $128 \pm 14 \mathrm{nM}$ with glucose and insulin $(P<0.05)$, and restored cellular responsiveness to insulin (Fig. 7), suggesting that glucose- and insulin-induced $\mathrm{Ca}^{2+}$ influx is responsible for the development of insulin resistance. Similar restoration of adipocyte response to insulin was achieved in preliminary experiments with nifedipine $(25 \mu \mathrm{M})$ or cobalt $(0.5 \mathrm{mM})$ (not shown), suggesting that a blockage of $\mathrm{Ca}^{2+}$ influx may ameliorate glucose- and insulin-induced insulin resistance.

\section{Discussion}

The present data directly demonstrate that both insulin and glyburide increase $\left[\mathrm{Ca}^{2+}\right] \mathrm{i}$ in human adipocytes. These find-

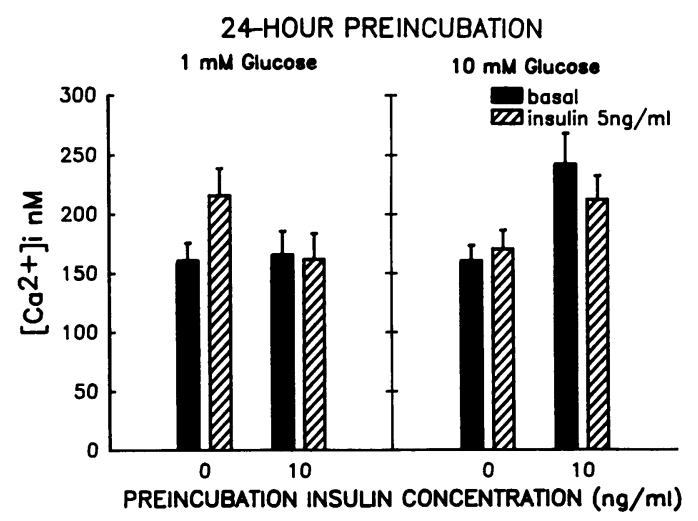

Figure 6. Effect of 24-h preincubation with 1 and $10 \mathrm{mM}$ glucose (with or without $10 \mathrm{ng} / \mathrm{ml}$ insulin) on basal and insulin-stimulated $\left[\mathrm{Ca}^{2+}\right] \mathrm{i}$ in rat adipocytes. Results represent the mean \pm SEM of five to eight experiments. 


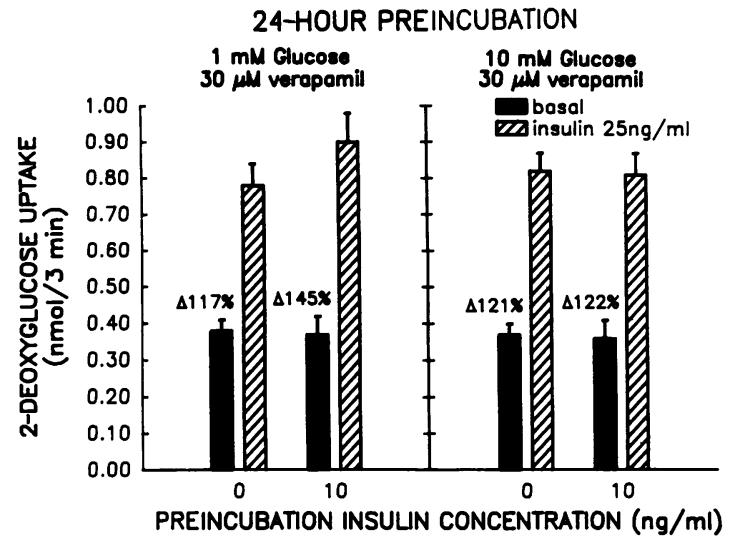

Figure 7. 2-Deoxyglucose uptake in adipocytes preincubated for $24 \mathrm{~h}$ with 1 and $10 \mathrm{mM}$ glucose (with or without $10 \mathrm{ng} / \mathrm{ml}$ insulin) in the presence of $\mathrm{Ca}^{2+}$ channel blocker verapamil $(30 \mu \mathrm{M})$. Results represent the mean \pm SEM of three to five experiments. $\Delta \%, \%$ stimulation.

ings support our previous observations using rat adipocytes (15), where both insulin and glyburide enhanced calcium influx via voltage-dependent calcium channels.

In this study, hyperinsulinemia induced by 3 and $6 \mathrm{~h}$ of insulin (and glucose) infusion not only increased $\left[\mathrm{Ca}^{2+}\right] \mathrm{i}$ in adipocytes obtained from normal volunteers, but made them unresponsive to either insulin or glyburide. This is not simply a desensitization of insulin action, because the effect of glyburide was also eliminated. The diminished responsiveness of adipocytes to insulin was also manifested by the reduced insulin-stimulated glucose uptake. Although the coexistence of these two phenomena does not prove causality, it is conceivable that impaired intracellular $\mathrm{Ca}^{2+}$ homeostasis contributes to the diminished cellular responsiveness to insulin.

It is interesting that in normal subjects hyperinsulinemia of relatively short duration induced the same degree of insulin and glyburide resistance as that seen in obese individuals. Indeed, obese patients demonstrated higher $\left[\mathrm{Ca}^{2+}\right] \mathrm{i}$ in the basal state and a lack of response to either insulin or glyburide in the adipocytes obtained even before the insulin infusion. During the course of the insulin infusion, $\left[\mathrm{Ca}^{2+}\right] \mathrm{i}$ remained elevated and unresponsive to the acute influence of either insulin or glyburide. These observations may indicate that obesity-associated high levels of intracellular free $\mathrm{Ca}^{2+}$ produce cellular resistance to insulin and glyburide. It is possible that these represent coexistent abnormalities that are not necessarily causally related.

In obese patients, mild to moderate weight loss $(8-12 \%)$ failed to reduce basal $\left[\mathrm{Ca}^{2+}\right] \mathrm{i}$ or restore adipocyte responsiveness to insulin and glyburide. The lack of improvement was not due to the levels of fasting insulinemia, since insulin levels in the obese patients were not different from controls $(6.5 \pm 1$ $\mu \mathrm{U} / \mathrm{ml})$ either before $(7.2 \pm 1 \mu \mathrm{U} / \mathrm{ml})$ or after $(6.8 \pm 2 \mu \mathrm{U} / \mathrm{ml})$ weight reduction. However, plasma insulin levels in obese patients $2 \mathrm{~h}$ after ingestion of $75 \mathrm{~g}$ glucose were significantly higher than in controls $(50 \pm 12 \mu \mathrm{U} / \mathrm{ml}$ before and $39 \pm 12$ $\mu \mathrm{U} / \mathrm{ml}$ after weight loss vs. $19 \pm 6 \mu \mathrm{U} / \mathrm{ml}$ in normals). It is rational to postulate that postprandial hyperinsulinemia remains a sufficient stimulus in maintaining high levels of intracellular $\mathrm{Ca}^{2+}$.

The in vitro experiments with glucose- and insulin-induced insulin resistance reported in this communication are in agreement with the in vivo data. In both cases, exposure of adipocytes to high glucose and insulin concentrations resulted in insulin resistance and increased levels of $\left[\mathrm{Ca}^{2+}\right] \mathrm{i}$. It would appear, therefore, that if hyperglycemia and hyperinsulinemia induce insulin resistance, this insensitivity must develop in part as the consequence of direct action of glucose and insulin on peripheral tissues (in this case, adipocytes).

It has been previously shown, both in vivo (22) and in vitro $(20,21,23)$, that exposure of adipocytes to high ambient insulin levels (particularly in the presence of higher levels of glucose) results in cellular insensitivity to subsequent insulin stimulation. The decrease in cellular sensitivity and responsiveness to insulin were attributed to insulin receptor and postreceptor defects, with the latter playing a predominant role (19-21, 23-26). Our data suggest that sustained high levels of intracellular $\mathrm{Ca}^{2+}$ may contribute to, if not initiate, the postreceptor defects. The fact that hyperinsulinemia and high levels of $\left[\mathrm{Ca}^{2+}\right] \mathrm{i}$ induced cellular resistance to glyburide suggests that $\left[\mathrm{Ca}^{2+}\right] \mathrm{i}$ may alter the cellular response to multiple agents. However, we did not study the gamut of agents stimulating glucose transport in adipocytes and therefore cannot draw any definitive conclusions.

Insulin has been shown to increase $\mathrm{Ca}^{2+}$ influx via voltagedependent $\mathrm{Ca}^{2+}$ channels $(15,18)$, and its effect was potentiated by higher ambient glucose concentrations (15). Insulin can also affect cellular $\mathrm{Ca}^{2+}$ homeostasis by inhibiting $\mathrm{Na}^{+}-\mathrm{K}^{+}$ ATPase and $\mathrm{Ca}^{2+}-\mathrm{Mg}^{2+}$ ATPase (for review, see references 4 and 11). The fact that verapamil restored the adipocytes' responsiveness to insulin does not necessarily imply that $\mathrm{Ca}^{2+}$ influx via voltage-dependent channels is the only mechanism whereby insulin and glucose increase $\left[\mathrm{Ca}^{2+}\right] \mathrm{i}$. The loci of cellular insulin and glucose action in increasing and maintaining high levels of $\left[\mathrm{Ca}^{2+}\right] \mathrm{i}$ need to be further investigated.

The precise mechanism whereby higher $\left[\mathrm{Ca}^{2+}\right] \mathrm{i}$ induces insulin resistance is unknown. We observed that in normal rat adipocytes, insulin-stimulated transport of 2-deoxyglucose was inhibited at both low (with calcium channel blockers) and high (with ionophore) concentrations of intracellular $\mathrm{Ca}^{2+}$ (18). Similarly, Bonne et al. (27) and Taylor et al. (28) have previously shown that excessive concentrations of calcium (above $5 \mathrm{mM}$ ) inhibited the effect of insulin on glucose transport in isolated adipocytes. These observations are consistent with the possibility that persistently high $\left[\mathrm{Ca}^{2+}\right] \mathrm{i}$ may contribute to the overall reduction in cellular response. The influence of changes in $\left[\mathrm{Ca}^{2+}\right] \mathrm{i}$ on both receptor and postreceptor steps of insulin action has not been studied. Further investigations in this area may provide new insights into the pathogenesis of insulin resistance.

The present data demonstrate that insulin and glyburide are capable of increasing $\left[\mathrm{Ca}^{2+}\right] \mathrm{i}$ in isolated human adipocytes. In a relatively short interval of time, using an insulin infusion, it is possible to induce resistance to the action of insulin and glyburide in adipocytes of normal subjects. These findings also suggest that under certain circumstances (hyperinsulinemia and/or obesity) increased $\left[\mathrm{Ca}^{2+}\right] \mathrm{i}$ may be a factor in inducing insulin resistance.

\section{Acknowledgments}

The authors greatly appreciate the excellent secretarial assistance of Gloria Smith. 
This work was supported by the Veterans Administration Medical Research Service, grants from the National Institutes of Health (AM-26356), the Upjohn Company, and the Mead-Johnson Nutritional Division.

\section{References}

1. Clausen, T., J. Elbrink, and B. R. Martin. 1974. Insulin controlling calcium distribution in muscle and fat cells. Acta Endocrinol. 77:137-143.

2. Kissebah, H. A., H. Hope-Gill, N. Vydelingum, B. R. Tullock, P. V. Clarke, and T. R. Fraser. 1975. Mode of insulin action. Lancet i:144-147.

3. Clausen, T. 1980. The role of calcium in the activation of the glucose transport system. Cell Calcium. 1:311-325.

4. Pershadsingh, H. A., and J. M. McDonald. 1984. Hormone-receptor coupling and the molecular mechanism of insulin action in the adipocyte: a paradigm for $\mathrm{Ca}^{2+}$ homeostasis in the initiation of the insulin-induced metabolic cascade. Cell Calcium. 5:111-130.

5. Bihler, I., P. Charles, and P. C. Sawh. 1980. Effects of the calcium ionophore A-23187 on the regulation of sugar transport in muscle. Cell Calcium. 1:327-336.

6. Klip, A. 1984. Is intracellular $\mathrm{Ca}^{2+}$ involved in insulin stimulation of sugar transport? fact and prejudice. Can. J. Biochem. 62:12281236.

7. Klip, A., G. Li, and W. J. Logan. 1984. Role of calcium ions in insulin action on hexose transport in L6 muscle cells. Am. J. Physiol 247:E297-E304.

8. Desai, K. S., B. Zinman, G. Steiner, and C. H. Hollenberg. 1978. Effect of calcium on $\left[{ }^{125} \mathrm{I}\right] \mathrm{insulin}$ binding to rat adipocytes. Can. $J$ Biochem. 56:844-848.

9. Plehwe, W. E., P. F. Williams, I. D. Caterson, L. C. Harrison, and J. R. Turtle. 1983. Calcium-dependence of insulin receptor phosphorylation. Biochem. J. 214:361-366.

10. Graves, C. B., R. D. Gale, J. P. Laurino, and J. M. McDonald. 1976. The insulin receptor and calmodulin: calmodulin enhances insulin-mediated receptor kinase activity and insulin stimulates phosphorylation of calmodulin. J. Biol. Chem. 261:10429-10438.

11. McDonald, J. M., and H. A. Pershadsingh. 1985. The role of calcium in the transduction of insulin action. In Molecular Basis of Insulin Action. M. Czech, editor. Plenum Publishing Corp., New York. 103-117.

12. McDonald, J. M., D. E. Bruns, and L. Jarett. 1976. Ability of insulin to increase calcium binding by adipocyte plasma membranes. Proc. Natl. Acad. Sci. USA. 73:1542-1546.

13. Goewert, R. R., N. B. Klaven, and J. M. McDonald. 1983. Direct effect of insulin on the binding of calmodulin to rat adipocyte plasma membranes. J. Biol. Chem. 258:9995-9999.

14. Pershadsingh, H. A., and J. M. McDonald. 1979. Direct addi- tion of insulin inhibits a high affinity $\mathrm{Ca}^{2+}$-ATPase in isolated adipocyte plasma membrane. Nature (Lond.). 281:495-497.

15. Draznin, B., M. Kao, and K. E. Sussman. 1987. Insulin and glyburide increase cytosolic free $\mathrm{Ca}^{2+}$ concentration in isolated rat adipocytes. Diabetes. 36:174-178.

16. Sadur, C. N., and R. H. Eckel. 1982. Insulin stimulation of adipose tissue lipoprotein lypase: use of euglycemic change technique J. Clin. Invest. 69:1119-1125.

17. Rodbell, M. 1964. Metabolism of isolated fat cells. J. Biol. Chem. 239:375-380.

18. Draznin, B., K. E. Sussman, M. Kao, D. Lewis, and N. Sherman. 1987. The existence of an optimal range of cytosolic free calcium for insulin-stimulated glucose transport in rat adipocytes. J. Biol. Chem. 262:14385-14388.

19. Marshall, S., W. T. Garvey, and M. Geller. 1984. Primary culture of isolated adipocytes: a new model to study insulin receptor regulation and insulin action. J. Biol. Chem. 259:6376-6384.

20. Garvey, W. T., J. M. Olefsky, S. Matthaei, and S. Marshall. 1987. Glucose and insulin co-regulate the glucose transport system in primary cultured adipocytes: a new mechanism of insulin resistance. $J$. Biol. Chem. 262:189-197.

21. Sinha, M. K., L. G. Taylor, W. J. Poriers, E. G. Flickinger, D. Meelheim, S. Atkinson, N. S. Sehgal, and J. F. Caro. 1987. Long-term effect of insulin on glucose transport and insulin binding in cultured adipocytes from normal and obese humans with and without non-insulin dependent diabetes. J. Clin. Invest. 80:1073-1081.

22. Mandarino, L., B. Baker, R. Rizza, J. Genest, and J. Gerich 1984. Infusion of insulin impairs human adipocyte glucose metabolism in vitro without decreasing adipocyte receptor binding. Diabetologia. 27:358-363.

23. Kashiwagi, M., A. Verso, J. Andres, B. Vasquez, G. Reaven and J. E. Foley. 1983. In vitro insulin resistance of human adipocytes isolated from subjects with non-insulin dependent diabetes mellitus. $J$. Clin. Invest. 72:1246-1254.

24. Freidenberg, G., R. R. Henry, H. H. Klein, D. R. Reichart, and J. M. Olefsky. 1987. Decreased kinase activity of insulin receptors from adipocytes of non-insulin dependent diabetic subjects. J. Clin. Invest. 79:240-250.

25. Lonnroth, P., M. DiGiralamo, and U. Smith. 1983. Influence of ambient glucose and insulin concentrations on adipocyte insulin binding. Metab. Clin. Exp. 32:609-614.

26. Garvey, W. T., J. M. Olefsky, and S. Marshall. 1986. Insulin induces progressive insulin resistance in cultured rat adipocytes: sequential effects at receptor and multiple post-receptor sites. Diabetes. 35:258-267.

27. Bonne, D., O. Belhadj, and P. Cohen. 1977. Modulation by calcium of the insulin action. Eur. J. Biochem. 75:101-105.

28. Taylor, W. M., L. Hau, and M. L. Halperin. 1979. Stimulation of glucose transport in rat adipocytes by calcium. Can. J. Biochem. 57:692-699. 